\title{
METODE NAIVE BAYES UNTUK PENENTUAN PENERIMA BEASISWA BIDIKMISI UNIVERSITAS MULAWARMAN
}

\author{
Diasrina Dahri' ${ }^{1)}$, Fahrul Agus ${ }^{2)}$, Dyna Marisa Khairina ${ }^{3)}$ \\ ${ }^{1,2,3)}$ Program Studi Ilmu Komputer, Fakultas Ilmu Komputer dan Teknologi Informasi, Universitas Mulawarman \\ Jalan Barong Tongkok Kampus Gunung Kelua Samarinda, Kalimantan Timur \\ Email : dias.rina@ymail.com ${ }^{1)}$, fahrulagus@gmail.com²),
}

\begin{abstract}
ABSTRAK
Kurang lebih 900 pendaftar beasiswa bidikmisi Universitas Mulawatman setiap tahun, menyebabkan proses seleksinya berjalan lamban dan berpotensi tidak konsisten. Ketidakkonsistenan pada sistem penentuan penerima menyebabkan tujuan penyelenggaraan beasiswa menjadi kabur, tidak transparan dan tidak tepat sasaran. Penelitian ini bertujuan untuk membantu bagian proses seleksi dengan membuat aplikasi perangkat lunak sistem pendukung keputusan untuk penentuan penerima beasiswa bidikmisi Universita Mulawarman. Penentuan penerima beasiswa menggunakan beberapa kriteria antara lain: pekerjaan orang tua, penghasilan orang tua, jumlah tanggungan, daya listrik (watt), dan nilai ujian nasional. Kelayakan calon penerima beasiswa bidikmisi ditentukan dengan menerapkan metode Nä̈ve Bayes. Metode ini dipilih karena mampu mempelajari data kasus sebelumnya yag digunakan sebagai data uji. Penelitian ini telah menghasilkan sebuah aplikasi sistem pendukung keputusan dengan tingkat akurasi sebesar $85.56 \%$.
\end{abstract}

Kata Kunci : Beasiswa Bidikmisi, Sistem Pendukung Keputusan, Naive Bayes

\section{PENDAHULUAN}

\section{Latar Belakang}

Setiap lembaga pendidikan khususnya universitas, terdapat banyak sekali jenis beasiswa yang ditawarkan kepada mahasiswanya. Salah satu jenis beasiswa yang ditawarkan Universitas Mulawarman yaitu beasiswa bidikmisi. Program beasiswa ini diperuntukkan bagi para siswa SMA/SMK/MA/MAK berprestasi yang telah lulus jalur SNMPTN, SMMPTN, dan SBMPTN di semua jurusan Universitas Mulawarman namun berasal dari orangtua/wali yang kurang mampu secara ekonomi.

Calon penerima beasiswa bidikmisi yang mencapai lebih dari 900 calon dari semua jalur, menyebabkan proses penyeleksian secara manual dirasa kurang efektif, baik dalam mencapai tujuan maupun dalam waktu penyeleksiannya. Dengan demikian dibutuhkan suatu sistem yang dapat merekomendasi pihak penyeleksi beasiswa bidikmisi dalam membuat keputusan penerima beasiswa dengan cepat dan juga tepat sasaran.

Pada sistem yang dibuat, selanjutnya untuk probabilitas tidak layak mendapatkan beasiswa akan didefinisikan sebagai $\mathrm{C}_{0}$ sedangkan untuk kelas layak mendapatkan beasiswa akan didefinisikan sebagai $\mathrm{C}_{1}$. Sistem pendukung keputusan yang dibangun diharapkan dapat membantu tim penyeleksi penerima beasiswa bidikmisi dalam memilih penerima beasiswa yang tepat sasaran.

\section{LANDASAN TEORI}

\subsection{Sistem Pendukung Keputusan}

Decision Support System atau Sistem Pendukung Keputusan yang biasa disingkat dengan
SPK secara umum didefinisikan sebagai sebuah sistem untuk mendukung para pengambil keputusan manajerial dalam situasi keputusan semiterstruktur. SPK dimaksudkan menjadi alat bantu bagi para pengambil keputusan untuk memperluas kapabilitas mereka, namun tidak untuk menggantikan penilaian mereka [12].

SPK tidak dimaksudkan untuk mengotomatisasikan pengambilan keputusan, tetapi memberikan perangkat interaktif yang memungkinkan pengambilan keputusan untuk melakukan berbagai analisis menggunakan modelmodel yang tersedia [8]. Model konseptual SPK dijelaskan pada Gambar 1. Adapun komponen komponen dari SPK yaitu :

1. Data Management

Termasuk database, yang mengandung data yang relevan untuk berbagai situasi dan diatur oleh software yang disebut Database Management System (DBMS).

2. Model Management

Melibatkan model finansial, statistikal, management science, atau berbagai model kualitatif lainnya, sehingga dapat memberikan ke sistem suatu kemampuan analitis, dan manajemen perangkat lunak yang dibutuhkan.

3. Communication

User dapat berkomunikasi dan memberikan perintah pada DSS melalui subsistem ini. Ini berarti menyediakan antarmuka.

4. Knowledge Management

Subsistem optional ini dapat mendukung subsistem lain atau bertindak atau bertindak sebagai komponen yang berdiri sendiri. 


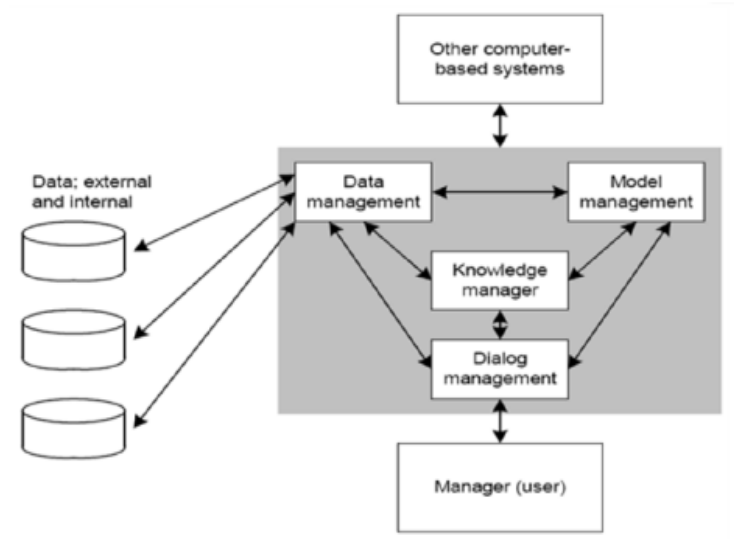

Gambar 1. Model konseptual SPK (Sumber : Subakti , 2002)

\subsection{Beasiswa Bidikmisi}

Dijelaskan di dalam Pedoman Penyelenggaraan Bantuan Biaya Pendidikan Bidikmisi oleh Direktorat Jenderal Pendidikan Tinggi, Program Bantuan Biaya Pendidikan Bidikmisi yang dimulai peluncuran programnya pada tahun 2010 ini adalah bantuan biaya pendidikan bagi calon mahasiswa tidak mampu secara ekonomi dan memiliki potensi akademik baik untuk menempuh pendidikan di perguruan tinggi pada program studi unggulan sampai lulus tepat waktu.

Adapun persyaratan bagi para calon pendaftar beasiswa bidikmisi [2]:

1. Siswa SMA/SMK/MA/MAK atau bentuk lain yang sederajat yang akan lulus pada tahun 2014;

2. Lulusan tahun 2013 yang bukan penerima Bidikmisi dan tidak bertentangan dengan ketentuan penerimaan mahasiswa baru di masing-masing perguruan tinggi;

3. Usia paling tinggi pada saat mendaftar adalah 21 tahun;

4. Tidak mampu secara ekonomi dengan kriteria:

a. Siswa penerima Beasiswa Siswa Miskin (BSM);

b. Pemegang Kartu Pengaman Sosial (KPS) atau sejenisnya;

c. Pendapatan kotor gabungan orangtua/wali (suami istri) sebesar-besarnya Rp3.000.000,00 per-bulan. Untuk pekerjaan nonformal/informal pendapatan yang dimaksud adalah rata-rata penghasilan per bukan dalam satu tahun terakhir; dan atau

d. Pendapatan kotor gabungan orangtua/wali dibagi jumlah anggota keluarga sebesarbesarnya Rp750.000,00 setiap bulannya;

5. Pendidikan orang tua/wali setinggi-tingginya S1 (Strata 1) atau Diploma 4.

6. Berpotensi akademik baik berdasarkan rekomendasi kepala sekolah.

7. Pendaftar difasilitasi untuk memilih salah satu diantara PTN atau PTS dengan ketentuan:

1. PTN dengan pilihan seleksi masuk:
- Seleksi Masuk Perguruan Tinggi Negeri (SNMPTN);

- Seleksi Bersama Masuk Perguruan Tinggi Negeri (SBMPTN);

- Seleksi mandiri di 1(satu) PTN.

2. PTS dengan pilihan seleksi masuk di 1 (satu) PTS.

\subsection{Metode Naïve Bayes}

Naïve Bayes merupakan metode probabilistik pengklasifikasian sederhana berdasarkan Teorema Bayes dimana pengklasifikasian dilakukan melalui training set sejumlah data secara efisien [3]. Naïve bayes mengasumsikan bahwa nilai dari sebuah input atribut pada kelas yang diberikan tidak tergantung dengan nilai atribut yang lain [11]. Teorema Bayes sendiri dikemukakan oleh ilmuwan Inggris Thomas Bayes, yaitu memprediksi peluang di masa depan berdasarkan pengalaman di masa sebelumnya sehingga dikenal sebagai Teorema Bayes. Dimana persamaan Teori Bayes tersebut adalah:

$$
P(C \mid X)=\frac{P(X \mid C) P(C)}{P(X)}
$$

Dimana :

$\mathrm{X}$ : Data dengan kelas yang belum diketahui

C : Hipotesis data X merupakan suatu kelas spesifik

$\mathrm{P}(\mathrm{C} \mid \mathrm{X})$ : Probabilitas hipotesis $\mathrm{C}$ berdasar kondisi $\mathrm{X}$ (probabilitas posterior)

$\mathrm{P}(\mathrm{C}) \quad$ : Probabailitas hipotesis $\mathrm{C}$ (probabilitas prior)

$\mathrm{P}(\mathrm{X} \mid \mathrm{C})$ : Probablitas $\mathrm{X}$ berdasarkan kondisi pada hipotesis $\mathrm{C}$

$\mathrm{P}(\mathrm{X}) \quad$ : Probabilitas X

Untuk menjelaskan teorema Naive Bayes, perlu diketahui bahwa proses klasifikasi memerlukan sejumlah petunjuk untuk menentukan kelas apa yang cocok bagi sampel yang dianalisis tersebut [9]. Karena itu, teorema bayes pada persamaan (1) disesuaikan menjadi persamaan (2) :

$P(C \mid X 1 \ldots X n)=\frac{P(C) P(X 1 \ldots X n \vee C)}{P(X 1 \ldots X n)}$

Dimana Variabel C merepresentasikan kelas, sementara variabel $\mathrm{X} 1 \quad \ldots \mathrm{Xn}$ merepresentasikan karakteristik petunjuk yang dibutuhkan untuk melakukan klasifikasi atau kriteria. Maka rumus tersebut menjelaskan bahwa peluang masuknya sampel karakteristik tertentu dalam kelas C (Posterior) adalah peluang munculnya kelas $\mathrm{C}$ (sebelum masuknya sampel tersebut, seringkali disebut prior), dikali dengan peluang kemunculan karakteristik-karakteristik sampel pada kelas C (disebut juga likelihood), dibagi dengan peluang kemunculan karakteristik-karakteristik sampel secara global ( disebut juga evidence). Karena itu, rumus diatas dapat pula ditulis secara sederhana pada persamaan (3) : 


$$
\text { Posterior }=\frac{\text { Priorxlikelihood }}{\text { evidence }}
$$

Nilai Evidence selalu tetap untuk setiap kelas pada satu sampel. Nilai dari posterior tersebut nantinya akan dibandingkan dengan nilai nilai posterior kelas lainnya untuk menentukan ke kelas apa suatu sampel akan diklasifikasikan. Penjabaran lebih lanjut rumus Bayes tersebut dilakukan dengan menjabarkan $(\mathrm{C} \mid \mathrm{X} 1, \ldots, \mathrm{Xn})$ menggunakan aturan perkalian sebagai berikut :

$P(C \mid X 1, \ldots, X n)=P(C) P(X 1, \ldots, X n \mid C)$

$P(C) P(X 1 \mid C) P(X 2, \ldots, X n \mid C, X 1)$

$P(C) P(X 1 \mid C) P(X 2 \mid C, F 1) P(X 3, \ldots, X n \mid C, X 1, X 2)$

$P(C) P(X 1 \mid C) P(X 2 \mid C, X 1) P(X 3, \ldots, X n \mid C, X 1, X 2, X 3)$

$P(C) P(X 1 \mid C) \ldots P(X n \mid C, X 1, X 3, \ldots, X n-1)$

Dapat dilihat bahwa hasil penjabaran tersebut menyebabkan semakin banyak dan semakin kompleksnya faktor-faktor syarat yang mempengaruhi nilai probabilitas, yang hampir mustahil untuk dianalisa satu persatu. Akibatnya, perhitungan tersebut menjadi sulit untuk dilakukan. Disinilah digunakan asumsi independensi yang sangat tinggi (naï), bahwa masing-masing kriteria $(\mathrm{X} 1, \mathrm{X} 2, \ldots, \mathrm{Xn})$ saling bebas (independen) satu sama lain. Dengan asumsi tersebut, maka berlaku persamaan (4) :

$$
\begin{gathered}
P(P i \mid X j)=\frac{P(X i \cap X j)}{P(X j)}=\frac{P(X i) P(X j)}{P(X j)} \\
=P(X i)
\end{gathered}
$$

Untuk i /= j, sehingga

$$
P(X i \mid C, X j)=P(X i \vee C)
$$

Dari persamaan (4) dapat disimpulkan bahwa asumsi independensi naïf tersebut membuat syarat peluang menjadi sederhana, sehingga perhitungan menjadi mungkin untuk dilakukan. Selanjutnya penjabaran $\mathrm{P}(\mathrm{C} \mid \mathrm{X} 1, \ldots, \mathrm{Xn})$ dapat disederhanakan menjadi persamaan (5):

$$
\begin{gathered}
P(X 2 \mid C) P(X 3 \mid C) \ldots \\
P(C \mid X 1, \ldots, X n)=P(X 1 \mid C) \\
=\prod_{i=1}^{n} P(X i \mid C)
\end{gathered}
$$

Keterangan :

$$
\prod_{i=1}^{n} P(X i \mid C)=\text { Perkalian rating antar atribut }
$$

Persamaan (5) merupakan model dari teorema Naïve Bayes yang selanjutkan akan digunakan dalam proses klasifikasi. Untuk klasifikasi dengan data kontinyu atau numeric digunakan rumus Densitas Gauss :

$$
P(X i=x i \mid C=c j) \frac{1}{\sqrt{2 \pi \sigma i j}} e^{\frac{-(f i-\mu i j)^{2}}{2 \sigma 2 i j}}
$$

Keterangan :

$P$ : Peluang

Xi : Atribut ke-i

xi : Nilai atribut ke-i

C : Kelas yang dicari

cj : Sub kelas $\mathrm{C}$ yang dicari

$\mu$ : Mean, menyatakan rata-rata dari seluruh atribut

$\sigma$ : Standar Deviasi, menyatakan varian dari seluruh atribut

$\pi \quad: 3.141592654$

e $: 2.718281828$

Naïve Bayes merupakan metode yang menggunakan pendekatan probabilitas untuk menghasilkan klasifikasi. Metode ini menggabungkan probabilitas term dengan probabilitas kategori untuk menentukan kemungkinan kategori berhasil. Dari penjelasan mengenai algoritma naïve bayes, dapat disimpulkan langkah-langkah pengerjaan Naïve Bayes adalah [3]:

Tentukan data latih dan data uji yang ingin diklasifikasikan. Menghitung $\mathrm{P}(\mathrm{Ci})$ yang merupakan probabilitas prior untuk setiap sub kelas $\mathrm{C}$ yang akan dihasilkan menggunakan persamaan:

$$
P(C i)=\frac{S i}{s}
$$

Dimana $\mathrm{Si}$ adalah jumlah data training dari kategori $\mathrm{Ci}$, dan s adalah jumlah total data training. Menghitung $\mathrm{P}(\mathrm{Xi} \mid \mathrm{Ci})$ yang merupakan probabilitas posterior $\mathrm{Xi}$ dengan syarat $\mathrm{C}$ menggunakan persamaan (5). Apabila xi merupakan data numerik, maka untuk mengitung $\mathrm{P}(\mathrm{Xi} \mid \mathrm{Ci})$ menggunakan distribusi gaussian yang terdapat pada persamaan (6).

Memaksimalkan $\quad \mathrm{P}(\mathrm{Xi} \mid \mathrm{Ci}) \cdot \mathrm{P}(\mathrm{Ci}) \quad$ untuk mendapatkan kelas $\mathrm{C}$ yang ingin diklasifikasikan dengan cara mengalikan $\mathrm{P}(\mathrm{X} \mid \mathrm{Ci})$ dan $\mathrm{P}(\mathrm{Ci})$ untuk semua kemungkinan klasifikasi :

$$
P(C i) \prod_{i=1}^{n} P(X i \mid C i)
$$

Dengan kata lain, hasil yang ditetapkan ke dalam kelas $\mathrm{Ci}$ adalah yang mempunyai $\mathrm{P}(\mathrm{Xi} \mid \mathrm{Ci}) \mathrm{P}(\mathrm{Ci})$ maksimum.

\subsection{Flowchart Diagram Proses Perhitungan Metode Naïve Bayes}

Bagan alir (flowchart) merupakan teknik analistis yang digunakan untuk menjelaskan aspekaspek system informasi secara jelas, tepat dan logis [7]. Diagram alir dari proses perhitungan dengan menggunakan metode Naïve Bayes dapat dilihat pada Gambar 2. 


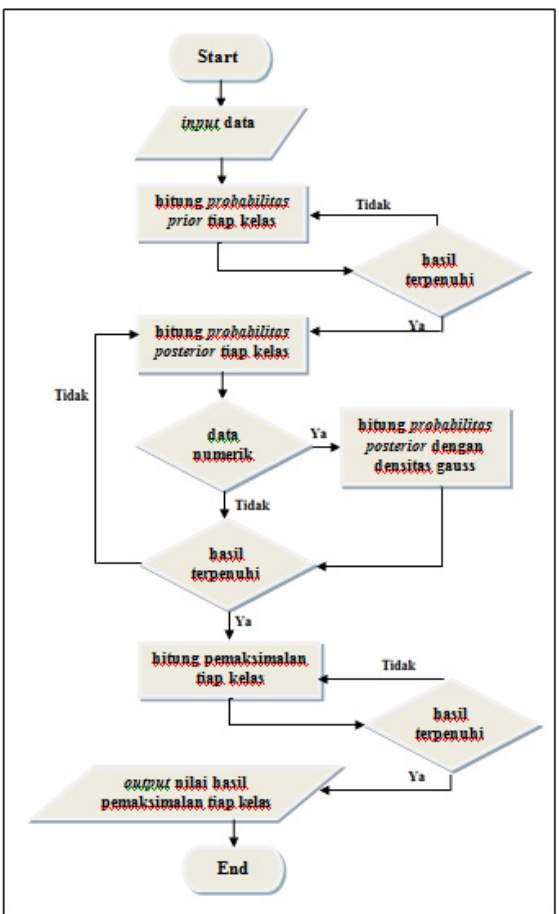

Gambar 2. Flowchart Diagram Proses Perhitungan Metode Naïve Bayes

\section{HASIL PENELITIAN PEMBAHASAN}

\section{A. Implementasi Sistem}

Implementasi Sistem merupakan tahapan realisasi yang dilakukan setelah rancangan aplikasi. Implementasi dilakukan untuk mengetahui hasil dari rancangan sistem yang telah dibangun.

\subsection{Desain Sistem User}

a. Halaman Login

Menu halaman Login dibuat untuk calon penerima beasiswa bidikmisi (user) jalur SNMPTN di Universitas Mulawarman agar dapat masuk ke halaman utama website beasiswa bidikmisi. Tampilan halaman login user dapat dilihat pada gambar 3 .

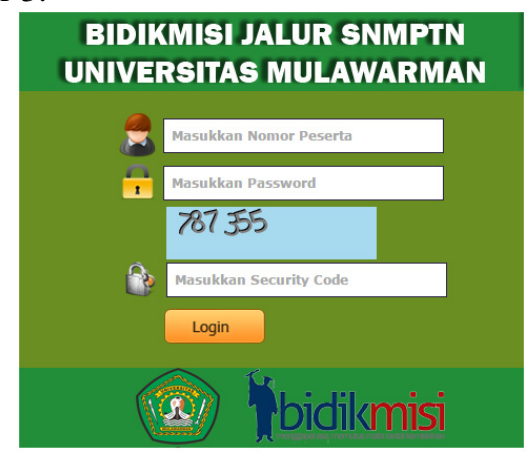

Gambar 3. Form Login User

Pada form login terdapat nomor peserta, password, dan security code yang harus diisi oleh user serta tombol "Login" untuk masuk ke halaman utama website beasiswa bidikmisi. Jika nomor peserta, password, dan security code yang diisi user benar, maka setelah mengklik "Login", user akan masuk ke halaman utama website beasiswa bidikmisi.

b. Halaman Utama

Setelah user berhasil login, yang muncul di awal adalah halaman utama website beasiswa bidikmisi sebagai menu pertama. Halaman utama bisa dilihat pada Gambar 4.

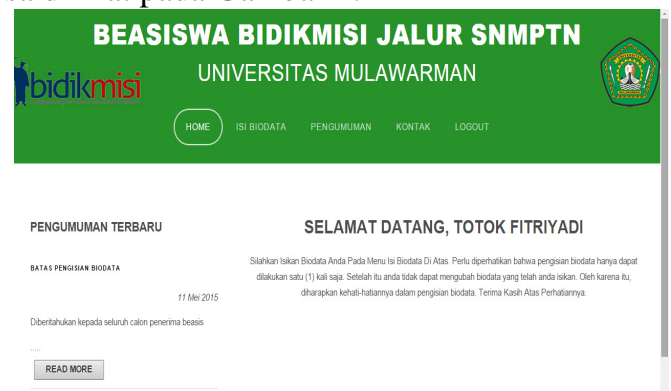

Gambar 4. Tampilan Halaman Utama Website Beasiswa Bidikmisi

c. Halaman Isi Biodata

Pada halaman ini, user diharuskan mengisi biodata yang tersedia. Biodata tersebut kemudian akan dihitung oleh sistem dengan menggunakan metode Naïve Bayes. Hasil rekomendasi layak/tidak layak user mendapat beasiswa akan langsung terlihat pada website administrator setelah user mengklik "Simpan" pada menu Isi Biodata. Lebih jelasnya tentang halaman Isi Biodata dapat dilihat pada gambar 5 .

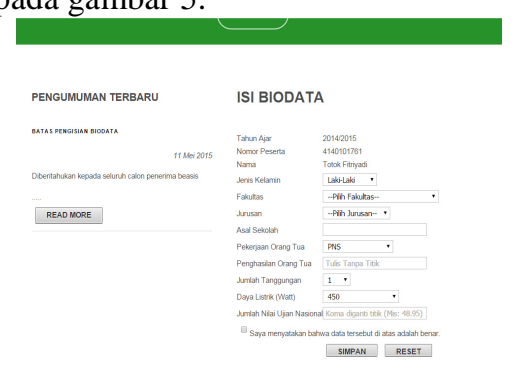

Gambar 5. Halaman Isi Biodata User

\subsection{Desain Sistem Admin}

a. Halaman Login Administrator

Menu halaman login dibuat untuk admin sebagai pengelola website beasiswa bidikmisi. Tampilan halaman login admin dapat dilihat pada gambar 6.

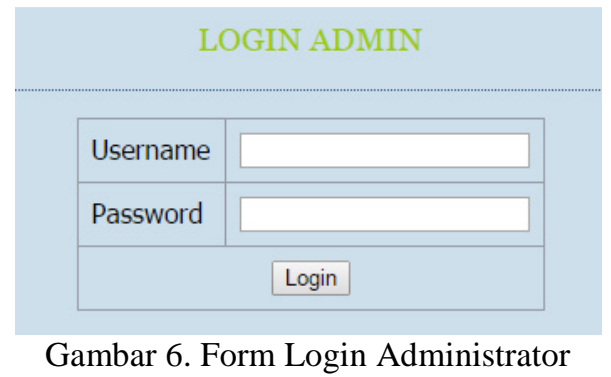

Pada form login admin, terdapat username dan password yang harus diisi oleh admin. Jika username dan password yang diisi oleh admin 
benar, maka setelah mengklik "Login", admin akan masuk ke halaman utama administrator.

\section{b. Halaman Utama Administrator}

Halaman admin hanya dapat diakses oleh user yang mempunyai hak akses sebagai admin. Seorang admin dapat melakukan berbagai pengaturan terhadap website beasiswa bidikmisi, antara lain mengelola pengumuman dan data user. Halaman utama administrator dapat dilihat pada gambar 7 .

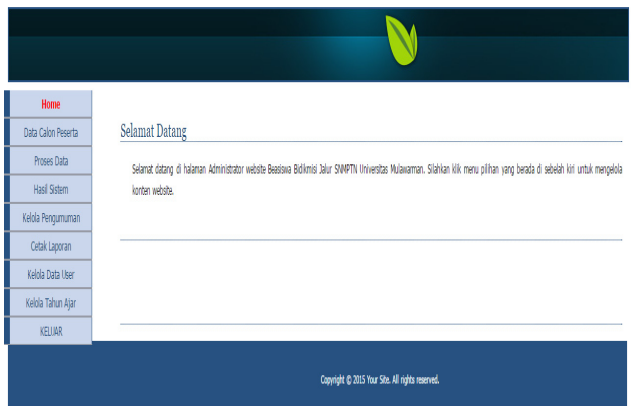

Gambar 7. Halaman Utama Website Administrator

\section{c. Halaman Data Calon Peserta}

Halaman data calon peserta digunakan admin untuk melihat data calon peserta yang telah mengisi biodata pada website beasiswa bidikmisi. Halaman data calon peserta dapat dilihat pada Gambar 8 .

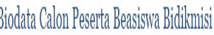

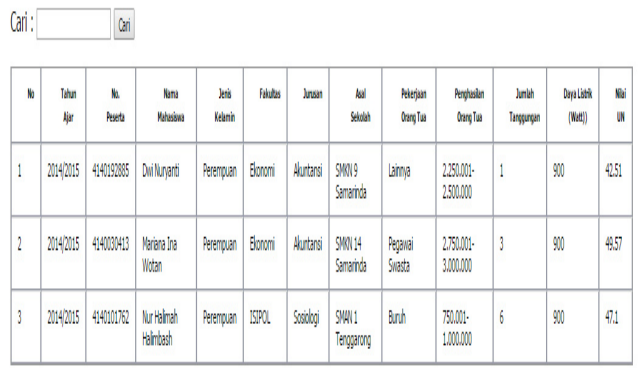

Gambar 8. Halaman Data Calon Peserta

\section{d. Halaman Proses Data}

Halaman proses data digunakan admin untuk melihat perhitungan yang dilakukan sistem dengan menggunakan metode Naïve Bayes berdasarkan data yang telah diinputkan oleh calon penerima beasiswa pada menu "Isi Biodata" yang terdapat pada website beasiswa bidikmisi. Tampilan halaman proses data dapat dilihat pada gambar 9 .

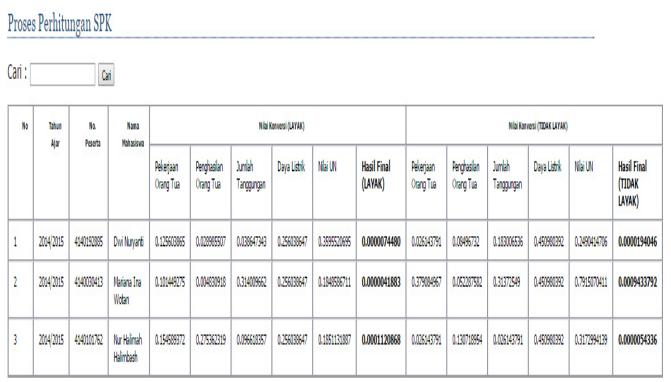

Gambar 9. Halaman Proses Data e. Halaman Hasil Sistem

Halaman hasil sistem digunakan admin untuk melihat hasil rekomendasi sistem apakah calon peserta tersebut layak/tidak layak mendapatkan beasiswa. Tampilan halaman hasil sistem dapat dilihat pada gambar 10 .

\section{Hasil Akhir Sistem}

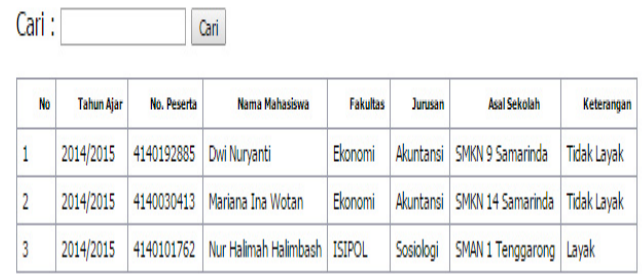

Gambar 10. Halaman Hasil Sistem

\section{B. Pengujian Sistem}

\section{Menyusun Kriteria dalam Bentuk Tabel Aturan}

Tabel aturan dibuat untuk menentukan penilaian dari masing-masing kriteria yang ada disajikan pada Tabel 1. Dari kriteria tersebut akan diperoleh hasil layak/tidak layak calon penerima beasiswa mendapatkan beasiswa. Tabel aturan diperoleh dari data latih yang digunakan sebagai acuan pehitungan data uji.

Tabel 1. Contoh Tabel Aturan

\begin{tabular}{|c|c|c|c|c|c|c|c|}
\hline .10 & $\begin{array}{c}\text { Nama } \\
\text { Mahasissra }\end{array}$ & $\begin{array}{l}\text { Pekerjaan } \\
\text { Ornng Tua }\end{array}$ & $\begin{array}{l}\text { Penghasilan } \\
\text { Orang Tua }\end{array}$ & \begin{tabular}{c|} 
Jumlah \\
Tanggungan
\end{tabular} & $\begin{array}{c}\text { Daya Listrilk } \\
\text { (Watt) }\end{array}$ & \begin{tabular}{|r|} 
Nilai Tjian \\
Nasional
\end{tabular} & Keterangan \\
\hline 1 & Nur $Y_{a d s a}$ & $\begin{array}{l}\text { Pegamail } \\
\text { Swasta }\end{array}$ & $\begin{array}{l}2.500 .001 \\
2.7500000\end{array}$ & 3 & 900 & 43.56 & TidakLayak \\
\hline 2 & $\begin{array}{l}\text { Khusnul } \\
\text { Khotima }\end{array}$ & PNS & $\begin{array}{l}4.000 .001- \\
4.250 .0000\end{array}$ & 4 & 1200 & 42.45 & Tidak Layak \\
\hline 3 & $\begin{array}{l}\text { Prisma Bella } \\
\text { Bangkit }\end{array}$ & Wirausaha & $\begin{array}{l}2.750 .001 \\
3.000 .000\end{array}$ & 2 & 900 & 51.20 & Tidak Layak \\
\hline 4 & $\begin{array}{l}\text { Anggita } \\
\text { Monika Puti }\end{array}$ & Bunh & $\begin{array}{l}750.001 . \\
1.000 .000\end{array}$ & 76 & $\begin{array}{l}\text { Surat } \\
\text { Keterangan }\end{array}$ & 49.22 & Layak \\
\hline 5 & Ruhanis & Petani & $\begin{array}{l}750.001 . \\
1.000 .000\end{array}$ & 5 & 900 & 45.73 & Layak \\
\hline 6 & $\begin{array}{l}\text { DiahIndah } \\
\text { Pemattasani }\end{array}$ & Wrausaha & $\begin{array}{l}1.500 .001- \\
1.7500000\end{array}$ & 2 & 450 & 47.4 & Tidak Layak \\
\hline 7 & Hikmah & Wirausaha & $\begin{array}{l}1.000 .001- \\
1.250 .000\end{array}$ & 5 & 450 & 47.83 & Layak \\
\hline 8 & Jumin & Petani & $250.001-500.000$ & 96 & 900 & 49.83 & Layak \\
\hline 9 & Anggageni K & $\begin{array}{l}\text { Pegamail } \\
\text { Swasta }\end{array}$ & $\begin{array}{l}1.750 .001- \\
2.000 .000\end{array}$ & 3 & 450 & 51.24 & Layak \\
\hline 10 & $\begin{array}{l}\text { Alldine Dyah } \\
\text { Cahya }\end{array}$ & Wirausaha & $\begin{array}{l}1.000 .001 \\
1.250 .000\end{array}$ & 4 & $\begin{array}{l}\text { Surat } \\
\text { Keterangan }\end{array}$ & 53.33 & Layak \\
\hline
\end{tabular}

Pendefinisian Variabel dan Kemungkinan Klasifikasi Ci merupakan kelas hasil klasifikasi dimana terdapat $\mathrm{C} 0$ yang merupakan kelas tidak layak menerima beasiswa dan $\mathrm{C} 1$ yang merupakan kelas layak menerima beasiswa. X merupakan data testing yang terdiri atas semua kriteria pemilihan penerima beasiswa bidikmisi yaitu Xpekerjaan orangtua, Xpenghasilan orangtua, Xtanggungan, Xdaya listrik, dan Xnilai ujian.

\section{Perhitungan Probabilitas Prior (P(Ci))}

Dari 278 data latih yang digunakan, diketahui kelas C0 (Tidak Layak) sebanyak 114 data, dan kelas C1(Layak) sebanyak 164 data. Perhitungan probabilitas prior untuk kemungkinan kelas tidak 
layak menerima beasiswa berdasarkan persamaan (7) :

$$
\mathrm{P}(\mathrm{C} 0) \frac{114}{278}=0.41
$$

Sedangkan perhitungan probabilitas prior untuk kemungkinan kelas layak menerima beasiswa $\mathrm{P}(\mathrm{C} 1)$ berdasarkan persamaan (7) :

$$
\mathrm{P}(\mathrm{C} 1)=\frac{164}{278}=0.59
$$

\section{Perhitungan Probabilitas Posterior $\mathrm{X}$ bersyarat C (P(X|Ci))}

Perhitungan probabilitas posterior dilakukan pada data latih sejumlah 278 data dengan menggunakan $\mathrm{X}$ yang merupakan vektor untuk kriteria pemilihan penerima beasiswa bidikmisi yaitu Xpekerjaan orangtua, Xpenghasilan orangtua, Xtanggungan, Xdaya listrik, dan Xnilai ujian sehingga $\mathrm{P}(\mathrm{X} \mid \mathrm{Ci})$ yang dijabarkan menjadi P(XXPekerjaan orangtua, XXPenghasilan orangtua, XXTanggungan, XXDaya listrik, dan XXNilai ujian $\mid \mathrm{Ci})$ dan untuk setiap $\mathrm{X}$ dihitung kemungkinannya terhadap $\mathrm{Ci}$.

Untuk menghitung setiap kemungkinan hasil kriteria pekerjaan orang tua untuk setiap kemungkinan $\mathrm{X}$ termasuk dalam kelas $\mathrm{Ci}$ (P(XPekerjaan orangtua|Ci)) dapat dilihat pada tabel 2.

Tabel 2. Tabel Probabilitas Pekerjaan Orang Tua

\begin{tabular}{|c|c|c|c|c|}
\hline \multirow{2}{*}{$\begin{array}{c}\text { Pekerjaan } \\
\text { Orang Tua }\end{array}$} & \multicolumn{2}{|c|}{ Jumlah Kejadian "Dipilih" } & \multicolumn{2}{|c|}{ Probabilitas $(\mathbf{P})$} \\
\cline { 2 - 5 } & Layak & Tidak layak & Layak $\left(\mathbf{C}_{1}\right)$ & Tidak Layak $\left(\mathbf{C}_{0}\right)$ \\
\hline PNS & 4 & 25 & 0.024390244 & 0.219298246 \\
\hline Pegawai Swasta & 19 & 39 & 0.115853659 & 0.342105263 \\
\hline Wirausaha & 36 & 20 & 0.219512195 & 0.175438596 \\
\hline TNI/Polin & 2 & 4 & 0.012195122 & 0.035087719 \\
\hline Petani & 48 & 15 & 0.292682927 & 0.131578947 \\
\hline Nelayan & 11 & 3 & 0.067073171 & 0.026315789 \\
\hline Buruh & 26 & 4 & 0.158536585 & 0.035087719 \\
\hline Lainnya & 18 & 4 & 0.109756098 & 0.035087719 \\
\hline Jumlah & 164 & 114 & 1 & 1 \\
\hline
\end{tabular}

Untuk menghitung setiap kemungkinan hasil kriteria penghasilan orang tua untuk setiap kemungkinan $\mathrm{X}$ termasuk dalam kelas $\mathrm{Ci}$ $(\mathrm{P}(\mathrm{XPenghasilan}$ orangtua|Ci) $)$ dapat dilihat pada tabel 3.

\begin{tabular}{|c|c|c|c|c|}
\hline \multirow{2}{*}{$\begin{array}{c}\text { Penghasilan Orang } \\
\text { Tua }\end{array}$} & \multicolumn{2}{|c|}{ Jumlah Kejadian "Dipilih" } & \multicolumn{2}{|c|}{ Probabilitas $(\mathbf{P})$} \\
\hline & Layak & Tidak layak & Layak $\left(\mathrm{C}_{1}\right)$ & Tidak Layak $\left(\mathrm{C}_{0}\right)$ \\
\hline$<=250.000$ & 7 & 0 & 0.042682927 & 0 \\
\hline $250.000-500.000$ & 23 & 0 & 0.140243902 & 0 \\
\hline $500.001-750.000$ & 25 & 0 & 0.15439024 & 0 \\
\hline $750.001-1.000 .000$ & 46 & 16 & 0.280487805 & 0.140350877 \\
\hline $1.000 .001-1.250 .000$ & 9 & 0 & 0.054878049 & 0 \\
\hline $1.250 .001-1.500 .000$ & 21 & 13 & 0.12804878 & 0.114035088 \\
\hline $1.500 .001-1.750 .000$ & 8 & 5 & 0.048780488 & 0.043859649 \\
\hline $1.750 .001-2.000 .000$ & 13 & 17 & 0.079268293 & 0.149122807 \\
\hline $2.000 .001-2.250 .000$ & 4 & 4 & 0.024390244 & 0.035087719 \\
\hline $2.250 .001-2.500 .000$ & 4 & 11 & 0.024390244 & 0.096491228 \\
\hline $2.500 .001-2.750 .000$ & 1 & 4 & 0.006097561 & 0.035087719 \\
\hline $2.750 .001-3.000 .000$ & 1 & 6 & 0.006097561 & 0.052631579 \\
\hline $3.000 .001-3.250 .000$ & 0 & 10 & 0 & 0.087719298 \\
\hline $3.250 .001-3.500 .000$ & 0 & 2 & 0 & 0.01754386 \\
\hline $3.500 .001-3.750 .000$ & 2 & 4 & 0 & 0.035087719 \\
\hline $3.750 .001-4.000 .000$ & 0 & 2 & 0.012195122 & 0.01754386 \\
\hline $4.000 .001-4.250 .000$ & 0 & 6 & 0 & 0.052631579 \\
\hline $4.250 .001-4.500 .000$ & 0 & 1 & 0 & 0.00877193 \\
\hline $4.500 .001-4.750 .000$ & 0 & 5 & 0 & 0.043859649 \\
\hline $4.750 .001-5.000 .000$ & 0 & 6 & 0 & 0.052631579 \\
\hline $5.000 .001-5.250 .000$ & 0 & 2 & 0 & 0.01754386 \\
\hline$>5.250 .000$ & 0 & 0 & 0 & 0 \\
\hline Jumlah & 164 & 114 & 1 & 1 \\
\hline
\end{tabular}

Tabel 3. Tabel Probablitas Penghasilan Orang Tua
Untuk menghitung setiap kemungkinan hasil kriteria penghasilan orang tua untuk setiap kemungkinan $\mathrm{X}$ termasuk dalam kelas $\mathrm{Ci}$ (P(XJumlah tanggungan|Ci)) dapat dilihat pada tabel 4.

Tabel 4. Tabel Probablitas Jumlah Tanggungan

\begin{tabular}{|c|c|c|c|c|}
\hline \multirow{2}{*}{$\begin{array}{c}\text { Jumlah } \\
\text { Tanggungan }\end{array}$} & \multicolumn{2}{|c|}{ Jumlah Kejadian "Dipilih" } & \multicolumn{2}{c|}{ Probabilitas $(\mathbf{P})$} \\
\cline { 2 - 5 } & Layak & Tidak layak & Layak $\left(\mathbf{C}_{1}\right)$ & Tidak Layak $\left(\mathbf{C}_{\mathbf{0}}\right)$ \\
\hline 1 & 5 & 18 & 0.030487805 & 0.157894737 \\
\hline 2 & 17 & 34 & 0.103658537 & 0.298245614 \\
\hline 3 & 50 & 40 & 0.304878049 & 0.350877193 \\
\hline 4 & 40 & 12 & 0.243902439 & 0.105263158 \\
\hline 5 & 17 & 7 & 0.103658537 & 0.061403509 \\
\hline 6 & 19 & 3 & 0.115853659 & 0.026315789 \\
\hline$>6$ & 16 & 0 & 0.097560976 & 0 \\
\hline Jumlah & 164 & 114 & 1 & 1 \\
\hline
\end{tabular}

Untuk menghitung setiap kemungkinan hasil kriteria penghasilan orang tua untuk setiap kemungkinan $\mathrm{X}$ termasuk dalam kelas $\mathrm{Ci}$ (P(XDaya listrik|Ci)) dapat dilihat pada tabel 5.

$$
\begin{aligned}
\sigma 2 & =\frac{\sum(\text { nilaiujian }-\mu)^{2}}{\sum(\text { seluruhdata }-1)}=\frac{1203.583253}{113} \\
& =10.65117923
\end{aligned}
$$

Tabel 5. Tabel Probabilitas Daya Listrik

\begin{tabular}{|c|c|c|c|c|}
\hline \multirow{2}{*}{$\begin{array}{c}\text { Daya Listrik } \\
\text { (Watt) }\end{array}$} & \multicolumn{2}{|c|}{ Jumlah Kejadian "Dipilih" } & \multicolumn{2}{c|}{ Probabilitas $(\mathbf{P})$} \\
\cline { 2 - 5 } & Layak & Tidak layak & Layak $\left(\mathbf{C}_{1}\right)$ & Tidak Layak $\left(\mathbf{C}_{\mathbf{0}}\right)$ \\
\hline 450 & 59 & 47 & 0.359756098 & 0.307189542 \\
\hline 900 & 40 & 69 & 0.243902439 & 0.450980392 \\
\hline 1200 & 8 & 32 & 0.048780488 & 0.209150327 \\
\hline 1300 & 3 & 5 & 0.018292683 & 0.032679739 \\
\hline 2200 & 0 & 0 & 0 & 0 \\
\hline S. Keterangan & 54 & 0 & 0.329268293 & 0 \\
\hline Jumlah & 164 & 114 & 1 & 1 \\
\hline
\end{tabular}

Dikarenakan kriteria nilai ujian nasional merupakan data numerik, maka untuk menghitung setiap kemungkinan hasil kriteria nilai ujian nasional untuk setiap kemungkinan $\mathrm{X}$ termasuk dalam kelas Ci (P(XNilai ujian|Ci)) harus dihitung menggunakan rumus Densitas Gauss pada persamaan (6).

Nilai Probabilitas Nilai Ujian berdasarkan kelas tidak layak menerima beasiswa.

Mencari Nilai Rata-rata $(\mu)$

$$
\begin{aligned}
\mu & =\frac{\text { Enilaiujian }}{\sum \text { seluruhdata }}=\frac{5152.38}{114} \\
& =45.1963158
\end{aligned}
$$

Mencari nilai varian $(\sigma 2)$

Mencari nilai standar deviasi $(\sigma)$

$$
\sigma=\sqrt{16.81772846}=3.263614442
$$

Sehingga, rumus menghitung probabilitas kriteria nilai ujian tidak layak mendapat beasiswa adalah:

$\mathrm{P}(\mathrm{XNilaiujian} \mid \mathrm{C} 0)=$

$$
\frac{1}{\sqrt{2 \pi} 3.263614442} e^{\frac{-(\text { Xnilaiujian }-45.1963158)^{2}}{2 .(10.65117923)}}
$$

Nilai Probabilitas Nilai Ujian berdasarkan kelas layak menerima beasiswa. 
Mencari Nilai Rata-rata $(\mu)$

$\mu=\frac{\text { Enilaiujian }}{\text { Sseluruhdata }}=\frac{7763.86}{164}=47.34060976$

Mencari nilai varian $(\sigma 2)$

$$
\begin{aligned}
\sigma 2 & =\frac{\sum(\text { nilaiujian }-\mu)^{2}}{\sum(\text { seluruhdata }-1)}=\frac{2741.289739}{163} \\
& =16.81772846
\end{aligned}
$$

Mencari nilai standar deviasi $(\sigma)$ $\sigma=\sqrt{16.81772846}=4.100942387$

Sehingga, rumus menghitung probabilitas kriteria nilai ujian layak mendapat beasiswa adalah: $\mathrm{P}(\mathrm{XNilai}$ ujian|C1)

$$
=\frac{1}{\sqrt{2 \pi} 4.100942387} e^{\frac{-(\text { Xnilaiujian }-47.34060976)^{2}}{2 .(16.81772846)}}
$$

\section{Pengujian Akurasi Sistem}

Dilakukan uji coba terhadap 368 data, dimana 278 data digunakan sebagai data latih dan 90 data digunakan sebagai data uji. Berdasarkan uji coba yang telah dilakukan serta melakukan perbandingan terhadap data sebenarnya, tentunya akan terdapat perbedaan. Dari perbedaan tersebut, akan dihitung nilai galat (error) dan nilai akurasinya. Nilai akurasi inilah yang akan menentukan kualitas dari aplikasi yang telah dibuat.

Untuk menghitung tingkat akurasi sistem:

$\begin{array}{ll}\text { Jumlah data uji } & =90 \\ \text { Jumlah data rekomendasi benar } & =77 \\ \text { Jumlah data rekomendasi salah } & =13\end{array}$

Nilai Galat $=\frac{\text { Jumlahdatarekomendasisalah }}{\text { Jumlahdatauji }} \times 100 \%$ $=\frac{13}{90} \times 100 \%$

$=14.44 \%$

Akurasi $=\frac{\text { Jumlahdatarekomendasibenar }}{\text { Jumlahdatauji }} \times 100 \%$

$$
\begin{aligned}
& =\frac{77}{90} \times 100 \% \\
& =85.56 \%
\end{aligned}
$$

Dari hasil pengujian yang dilakukan, aplikasi SPK seleksi penerima beasiswa bidikmisi mempunyai nilai galat sebesar $13.33 \%$ dan tingkat akurasi sebesar $86.67 \%$.

\section{Perhitungan Manual}

Berikut akan dicontohkan uji coba perhitungan manual untuk seleksi penerima beasiswa bidikmisi dengan menggunakan metode

\begin{tabular}{|c|c|c|c|c|c|}
\hline $\begin{array}{c}\text { Nama } \\
\text { Mahasisstra }\end{array}$ & $\begin{array}{l}\text { Pekerjaan } \\
\text { Orang Tua }\end{array}$ & $\begin{array}{l}\text { Penghasilan } \\
\text { Orang Tua }\end{array}$ & $\begin{array}{l}\text { Jumlah } \\
\text { Tanggunganl }\end{array}$ & $\begin{array}{c}\text { Daya Listrilk } \\
\text { (Watt) }\end{array}$ & $\begin{array}{l}\text {. Iilai Jjan } \\
\text { Tasional }\end{array}$ \\
\hline Nur Halimah & Bunh & 1.000 .000 & 6 & 900 & 47.1 \\
\hline
\end{tabular}
Naïve Bayes. Untuk melakukan perhitungan, dibutuhkan masukan data uji yang diambil secara

\begin{tabular}{|c|c|c|c|c|c|}
\hline $\begin{array}{c}\text { Nama } \\
\text { Mahasissra }\end{array}$ & $\begin{array}{l}\text { Pekerjaan } \\
\text { Orang Tua }\end{array}$ & $\begin{array}{l}\text { Penghasilan } \\
\text { Orang Tua }\end{array}$ & $\begin{array}{c}\text { Jumlah } \\
\text { Tangggungan }\end{array}$ & $\begin{array}{c}\text { Daya Listrik } \\
\text { (Watt) }\end{array}$ & $\begin{array}{c}\text { Nilai Cjajan } \\
\text { Nasional }\end{array}$ \\
\hline Nur Halimah & Bundh & $\begin{array}{l}750.001 . \\
1.000 .000\end{array}$ & 6 & 900 & 47.1 \\
\hline
\end{tabular}
acak sebagai berikut.

Tabel 6. Tabel Contoh Masukan Data Uji
Tabel 7. Tabel Contoh Pengolahan Data Uji

Tahapan perhitungan contoh data uji tersebut dilakukan sebagai berikut:

\section{a. Pendefinisian variabel}

Berdasarkan tabel 7, dapat dibuat definisi data uji X sebagai berikut:

$X=\left\{\right.$ XPekerjanOrangtua $=$ Buruh,$X_{\text {PenghasilanOrangtua }}=750.001$ 1.000.000, $\quad X_{\text {Jumlahtanggungan }}=6, \quad X_{\text {Dayalistrik }}=900$, $\left.\mathrm{X}_{\text {Nilaiujian }}=47.1\right\}$.

\section{b. Pendefinisian Probabilitas Prior $\mathbf{P}(\mathrm{Ci})$}

Hasil pendefinisian Probabilitas prior dilakukan berdasarkan persamaan (7) menghasilkan definisi untuk kelas tidak layak mendapatkan beasiswa $(\mathrm{P}(\mathrm{C} 0))$ diketahui sebesar 0.41 dan hasil pendefenisian Probabilitas prior untuk kelas layak mendapatkan beasiswa $(\mathrm{P}(\mathrm{C} 1))$ diketahui sebesar 0.59 .

\section{c. Perhitungan Probabilitas posterior $\mathrm{X}$ dengan syarat Ci $(\mathbf{P}(\mathrm{X} \mid \mathrm{Ci}))$}

Untuk perhitungan data uji $\mathrm{X}$ pada tabel 10 yang terklasifikasi ke dalam kelas tidak layak menerima beasiswa $\mathrm{P}(\mathrm{X} \mid \mathrm{C} 0)$ diketahui nilainya untuk masing-masing kriteria adalah 0.035087719, 0.140350877, 0.02615789, 0.456140351 . Sedangkan untuk $\mathrm{P}\left(\mathrm{X}_{\text {Nilai ujian }} \mid \mathrm{C} 0\right)$ harus dihitung terlebih dahulu menggunakan persamaan (11).

$\mathrm{P}\left(\mathrm{X}_{\text {Nilaiujian }} \mid \mathrm{C} 0\right)$

$$
\frac{1}{\sqrt{2 \pi} 3.263614442} e^{\frac{-(\text { Xnilaiujian }-45.1963158)^{2}}{2 .(10.65117923)}}
$$

$$
\begin{aligned}
\mathrm{P}\left(\mathrm{X}_{\text {Nilai ujian } \mid} \mathrm{C} 0\right)=\frac{1}{\sqrt{2 \pi} 3.263614442} & e^{\frac{-(47.1-45.1963158)^{2}}{2 .(10.65117923)}} \\
& =0.122239403 e^{\frac{3.624013533}{21.30235845}} \\
& =0.122239403 e^{0.4048386732} \\
& =0.1449087284
\end{aligned}
$$

Setiap nilai kriteria tersebut kemudian dikalikan:

$\mathrm{P}(\mathrm{X} \mid \mathrm{C} 0)=\quad \mathrm{P}\left(\mathrm{X}_{\text {PekerjaanOrangtua }=\mathrm{Buruh}} \mid \mathrm{C} 0\right) \quad \mathrm{X}$ $\mathrm{P}\left(\mathrm{X}_{\text {PenghasilanOrangtua }}=750.001-\quad 1.000 .000 \mid \mathrm{C} 0\right) \quad \mathrm{X}$ $\mathrm{P}\left(\mathrm{X}_{\text {Jumlahtanggungan }}=6 \mid \mathrm{C} 0\right) \quad \mathrm{x} \quad \mathrm{P}\left(\mathrm{X}_{\text {Dayalistrik }}=900 \mid \mathrm{C} 0\right) \quad \mathrm{x}$ $\mathrm{P}\left(\mathrm{X}_{\text {Nilaiujian }}=47.1 \mid \mathrm{C} 0\right)$

$$
\begin{aligned}
= & 0.035087719 \times 0.140350877 \times 0.02615789 \\
& \times 0.456140351 \times 0.1449087284 \\
= & 0.0000085660
\end{aligned}
$$

Untuk perhitungan data uji $\mathrm{X}$ yang terklasifikasi ke dalam kelas layak menerima beasiswa $\mathrm{P}(\mathrm{X} \mid \mathrm{C} 1)$ diketahui nilainya untuk masingmasing kriteria adalah $0.158536585,0.280487805$, $0.115853659,0.243902439$. Sedangkan untuk $\mathrm{P}(\mathrm{XNilai}$ ujian|C1) harus dihitung terlebih dahulu menggunakan persamaan (12). 


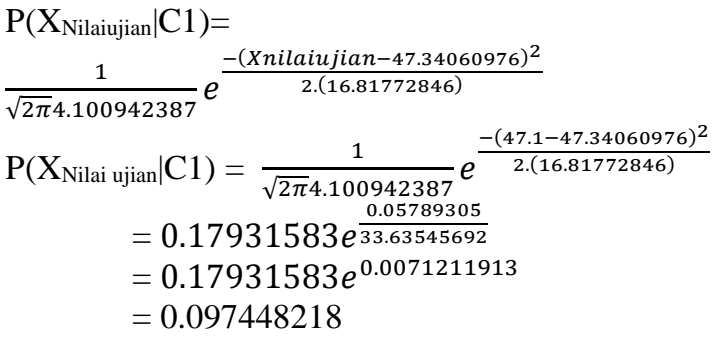
dikalikan:

$\mathrm{P}(\mathrm{X} \mid \mathrm{C} 1)=\quad \mathrm{P}\left(\mathrm{X}_{\text {PekerjaanOrangtua }=\text { Buruh }} \mid \mathrm{C} 1\right) \quad \mathrm{X}$ $\mathrm{P}\left(\mathrm{X}_{\text {PenghasilanOrangtua }}=750.001-\quad 1.000 .000 \mid \mathrm{C} 1\right) \quad \mathrm{X}$ $\mathrm{P}\left(\mathrm{X}_{\text {Jumlahtanggungan }}=6 \mid \mathrm{C} 1\right) \quad \mathrm{x} \quad \mathrm{P}\left(\mathrm{X}_{\text {Dayalistrik }}=900 \mid \mathrm{C} 1\right) \quad \mathrm{X}$ $\mathrm{P}\left(\mathrm{X}_{\text {Nilaiujian }}=47.1 \mid \mathrm{C} 1\right)$

$=0.158536585 \times 0.280487805 \times 0.115853659 \times$ $0.243902439 \times 0.097448218$ $=0.0001224456$

\section{d. Pemaksimalan $\mathbf{P}(\mathrm{X} \mid \mathrm{Ci}) \mathbf{P}(\mathrm{Ci})$}

Perhitungan pemaksimalan untuk kemungkinan klasifikasi ke dalam kelas tidak layak mendapat beasiswa adalah dengan mengalikan hasil $\mathrm{P}(\mathrm{X} \mid \mathrm{C} 0)$ dengan $\mathrm{P}(\mathrm{C} 0)$ :

$$
\begin{aligned}
& \mathrm{P}(\mathrm{C} 0 \mid \mathrm{X}) \quad \mathrm{P}(\mathrm{X} \mid \mathrm{C} 0) \times \mathrm{P}(\mathrm{C} 0) \\
& =0.0000085660 \times 0.41 \\
& =0.0000035121 \\
& \text { Perhitungan pemaksimalan untuk }
\end{aligned}
$$
kemungkinan klasifikasi ke dalam kelas layak. mendapat beasiswa adalah dengan mengalikan hasil $\mathrm{P}(\mathrm{X} \mid \mathrm{C} 1)$ dengan $\mathrm{P}(\mathrm{C} 1)$ :

$$
\begin{aligned}
\mathrm{P}(\mathrm{C} 1 \mid \mathrm{X}) & =\mathrm{P}(\mathrm{X} \mid \mathrm{C} 1) \times \mathrm{P}(\mathrm{C} 1) \\
& =0.0001224456 \times 0.59 \\
& =0.0000722429
\end{aligned}
$$

Dari perhitungan di atas didapatkan hasil $\mathrm{P}(\mathrm{C} 0 \mid \mathrm{X})$ adalah 0.0000035121 sedangkan $\mathrm{P}(\mathrm{C} 1 \mid \mathrm{X})$ adalah 0.000722429. Berdasarkan persamaan (8), dibuktikan bahwa $\mathrm{P}(\mathrm{C} 1 \mid \mathrm{X})>\mathrm{P}(\mathrm{C} 0 \mid \mathrm{X})$, maka untuk contoh data uji X diklasifikasikan masuk ke dalam kelas layak menerima beasiswa bidikmisi.

\section{KESIMPULAN}

Dari penelitian yang telah dilakukan, dapat diambil kesimpulan sebagai berikut:

1. Telah dibuat aplikasi Seleksi Penerima Beasiswa Bidikmisi Universitas Mulawarman dengan menggunakan metode Nä̈ve Bayes.

2. Penelitian ini berhasil menerapkan metode Nä̈ve Bayes untuk membantu menyeleksi penerima beasiswa bidikmisi, dengan tingkat akurasi sebesar $85.56 \%$.

\section{SARAN}

Adapun beberapa saran yang dapat diajukan antara lain:

1. Website dapat dikembangkan dalam bentuk dinamis dan tentunya dapat dikembangkan ke tahapan yang lebih kompleks dan terperinci, termasuk pada penambahan kriteria-kriteria penunjang pemilihan keputusan agar hasil yang didapat lebih maksimal.
2. Website dapat dikembangkan dengan tidak hanya menghitung calon peserta yang terdapat di jalur SNMPTN, tetapi bisa dibuat penambahan jalur SBMPTN atau jalur SMMPTN.

\section{DAFTAR PUSTAKA}

[1] Bustami. 2014. Penerapan Algoritma Naïve Bayes Untuk Mengklasifikasi Data Nasabah Asuransi. Jurnal Informatika. Vol. 8 No. 1. Aceh.

[2] Dikti. 2014. Pedoman Penyelenggaraan Bantuan Biaya Pendidikan Bidikmisi. Jakarta : Dikti.

[3] Hadiyani. Eka Pratiwi. 2013. "Rancang Bangun Sistem Pendukung Keputusan Untuk Pemilihan Anggota Terbaik AIESEC Surabaya Dengan Menggunakan Metode Naive Bayes". Fakultas Sains dan Teknologi. Universitas Airlangga.

[4] Kadir, Abdul. 2008. Tuntunan Praktis Belajar database Menggunakan MySQL. Yogyakarta: Andi Offset.

[5] Kendall K. E \& J. E. Kendall. 2003. Analisis dan Perancangan Sistem. Alih Bahasa oleh Thamir Abdull Hasedh Al-Hamdany. Edisi 5. Jilid 1. Jakarta: Penerbit Pre Hallindo.

[6] Khairina, D.M., Awang, H.K., \& Welly, A. 2014. Implementation Of Naïve Bayes Methods In Recruitments Ship Officer. Prosiding Seminar Nasional Sains dan Teknologi Informasi. ISSN: 2355-536X. Makassar.

[7] Krismiaji. 2010. Sistem Informasi Akuntasi Edisi 3. Yogyakarta: AMP YKPN.

[8] Kusrini. 2007. Konsep Aplikasi Sistem Pendukung Keputusan. Yogyakarta : Andi.

[9] Natalius, Samuel. 2010. Metoda Naïve Bayes Classifier dan Penggunaannya pada Klasifikasi Dokumen. Sekolah Teknik Elektro dan Informatika Institut Teknologi Bandung. Bandung.

[10] Subakti, Irfan. 2002. Sistem Pendukung Keputusan. Institut Teknologi Sepuluh November. Surabaya.

[11] Tan, Pang-Ning., Steinbach, Michael., dan Kumar, Vipin. 2006. Introduction to Data Mining. Pearson Education. Boston.

[12] Turban, E., Aronso, J.E., \& Liang, T.P. 2005. Sistem pendukung Keputusan dan Sistem Cerdas. Terjemahan Dwi Prabantini. Yogyakarta : Andi.

[13] Wasiati, Hera., Wijayanti, Dwi. 2014. Sistem Pendukung Keputusan Penentuan Kelayakan Calon Tenaga Kerja Indonesia Menggunakan Metode Naïve Bayes (Studi Kasus: Di PT. Karyatama Mitra Sejati Yogyakarta). Indonesian Journal on Networking and Security Volume 3 No 2. Yogyakarta. 